\title{
A HISTÓRIA SERTANISTA DA CASA DE PEDRA DE AMARANTINA, NAS MINAS GERAIS: PATRIMÔNIO E IDENTIDADES LOCAIS
}

\author{
THE SERTANISTA HISTORY \\ OF THE CASA DE PEDRA IN \\ AMARANTINA, MINAS GERAIS: \\ HERITAGE AND LOCAL IDENTITIES
}

\section{RESUMO}

Integrando-se à extensão da Universidade Federal de Ouro Preto em 2014, o projeto de extensão Construindo a História Sertanista da Casa de Pedra de Amarantina, Ouro Preto nas Minas promoveu um trabalho coletivo de educação patrimonial, no distrito de Amarantina (Ouro Preto), e refletiu sobre uma política patrimonial articulada aos valores locais. Tratou-se de identificar e compreender um símbolo patrimonial da localidade, a Casa de Pedra ou Casa Setecentista, tombada pelo IPHAN em 1963, observando as expressões culturais, tempos de continuidade/descontinuidade do lugar, que, como camadas, pareciam sedimentar a Casa. Apresentamos um trabalho historiográico crítico, ponto de partida para a revisão da gênese/quadro de tombamento da Casa de Pedra, e supomos que esse percurso seria fundamental à (re) incorporação social do bem tombado. No trabalho coletivo (oficinas), confrontamos as conceituações fundamentais das ações, abordando o contexto histórico da Casa. Assim, escavamos a sedimentação do bem tombado, patrimonializado em decorrência de uma história bandeirista, e apontamos o horizonte dos diversos usos locais (além daquele do Patrimônio Histórico).

Palavras-chave: educação patrimonial; casa setecentista; Bandeirismo; patrimônio cultural.

\section{ABSTRACT:}

In 2014, an outreach project from the Federal University of Ouro Preto developed a collective work about heritage education in the district of Amarantina (Ouro Preto) that reflected about the importance of heritage policies linked to local values. The project aimed at identifying and understanding the local heritage symbol called Casa da Pedra or Casa Setecentista (Stone House or the $18^{\text {th }}$ century house), which was listed as cultural heritage by the IPHAN in 1963, observing the cultural expressions and continuity/

* Professora da Escola Estadual Francisco Escobar (EEFE), MG - Brasil. E-mail: polligercossimo@hotmail.com

** Professor da Universidade Federal de Ouro Preto (UFOP), MG - Brasil. E-mail: franciscoeandrade@hotmail.com 
discontinuity of times of the place, which like layers seemed to sediment the building. The article presents a critical historiographical research as the starting point for the review concerning the genesis/context of the Casa de Pedra, as this was considered essential to the social reincorporation of the property identified as cultural heritage. During the workshops, essential conceptualizations of the actions were discussed taking into consideration the historical context of the Casa da Pedra. Thus, the building, identified as part of the local heritage due to the bandeirista history was excavated and numerous possibilities of local uses have been pointed out in addition to that of Historical Heritage.

Keywords: heritage education; 18th century house; Bandeirismo; cultural heritage.

\section{Introduçáo}

O projeto de extensão Construindo a História Sertanista da Casa de Pedra de Amarantina, Ouro Preto nas Minas, distrito do município de Ouro Preto (Minas Gerais), integra-se ao planejamento da extensão da Universidade Federal de Ouro Preto no ano de 2014. Este projeto foi fruto do convite que a diretoria do Espaço Cultural Casa de Pedra de Amarantina, juntamente com a Secretaria de Cultura de Ouro Preto, fizeram a um grupo de estudiosos do patrimônio cultural. ${ }^{1}$

Nele, buscou-se promover uma atividade de educação patrimonial através de oficinas, junto aos moradores do distrito de Amarantina, abordando a expansão bandeirista ou sertanista nessa regiáo, nos séculos XVII e XVIII, e a sua configuração cultural e econômica. Tratou-se de apreender a história que fundamentaria a construçáo e os usos de gênese de um bem tombado pelo IPHAN, em 1963: a chamada Casa de Pedra, situada na povoação de Amarantina, antiga Sáo Gonçalo do Amarante, no município de Ouro Preto. ${ }^{2}$ Nesse sentido, focou-se na observação das expressóes locais e coletivas, que pareciam sedimentar a Casa na história da gênese que motivou seu tombamento.

Como estratégia inicial, realizamos um trabalho de levantamento historiográfico, o qual serviu de ponto de partida e/ou de fundamentaçáo teórica para a revisão da gênese/quadro de tombamento da Casa de Pedra/Sertanista/Bandeirista, conforme nossa suposição de que esse percurso seria fundamental para a (re)incorporação social do bem tombado, comprometendo-o com o devir dos locais.

A Casa de Pedra, assim comumente denominada pelos moradores, está localizada na confluência das ruas Santo Onofre e Padre Pedrosa, pouco distante da Igreja de São Gonçalo de Amarante. Ela é uma edificação grande, térrea e com alpendre. Pesquisas arqueológicas, assim como certa tradição popular, indicam que o edifício fora construído pelos bandeirantes paulistas, que entraram para o lugar em fins do século XVII. Trata-se de construção muito antiga, sendo incluída entre as chamadas Casas Bandeiristas. Assim sendo, conforme as pesquisas que subsidiaram o tombamento do IPHAN e a memorialística de Amarantina, a Casa Bandeirista do lugar seria resultante dessa tradiçáo ou do gênero de vida que remonta aos sertanistas oriundos do planalto de São Paulo.

Situada ao sopé do morro que conserva a matriz de São Gonçalo do Amarante, antiga capela de São Gonçalo do Tijuco, fundada nas primeiras décadas dos Setecentos, a Casa apresenta grossas paredes de pedra, material pouco comum nas edificações de tipo bandeirante, o que simboliza adaptação à matériaprima local, e, em contrapartida, assinala em suas dimensóes arquitetônicas uma lógica construtiva

1 Este grupo é formado por alunos de graduação, pós-graduação e professores do curso de História da Universidade Federal de Ouro Preto. Seus integrantes discutem, estudam e revisam toda uma historiografia tradicional da constituição e relação das identidades, territórios e patrimônios nas Minas Gerais. As reflexões podem ser \acessadas em: http://gphmufop.wixsite.com/ historiografia.

2 Projeto de pesquisa arqueológica da Casa Setecentista (Casa de Pedra) Amarantina - Ouro Preto/MG. Relatório final, v. 2, julho de 2014. [impresso] 
tipicamente paulista ou, quando menos, de procedência e inspiração da "arquitetura bandeirista".

Nada se sabe acerca dos usos do imóvel durante o século XIX. Na primeira metade do século XX, a edificaçáo já estava desocupada, embora ainda estivesse mais ou menos preservada. Seu aspecto chamou a atenção de alguns pesquisadores e possibilitou o reconhecimento pelo Patrimônio Histórico e Artístico Nacional, que efetuou o tombamento em 10/07/1963, conforme o processo 0472-T, inscrição 362 no Livro de Tombo Histórico. ${ }^{4}$ A edificação foi então intitulada, pelos técnicos do IPHAN, de "Casa Setecentista". Contudo, esse ato não teve repercussão local, porque a Casa passou a atender objetivos e usos que nem sempre favoreciam à sua conservaçáo. Em 2001, ela foi apropriada pela comunidade para que se construísse uma praça e, somente em 2008, retornou à administração da Prefeitura Municipal de Ouro Preto, que iniciou obras de restauração.

Em 2014, foi inaugurado o Espaço Cultural da Casa Bandeirista de Amarantina ECCOAR 5 , quando ela passou a ser designada, pelo menos nos planos de Espaço Cultural, "Casa Bandeirista" ou simplesmente Casa de Pedra. Neste sentido, a Casa de Pedra possui três gêneses que dialogam entre si: a do século XVIII, como um espaço sertanista; a do IPHAN, como Casa Setecentista; e, por fim, a do ECCOAR, como Casa Bandeirista.

Portanto, a história da Casa sedimentada por seu tombamento náo permitiu que os moradores locais ampliassem os usos daquele espaço. Neste sentido, eles ficavam presos àquela história engessada, que muitas vezes não os representava só por ser ela uma história tombada, patrimonializada. Os moradores locais não conseguiam perceber que aquele espaço poderia abrigar diversas histórias locais, sem a exclusão uma da outra.

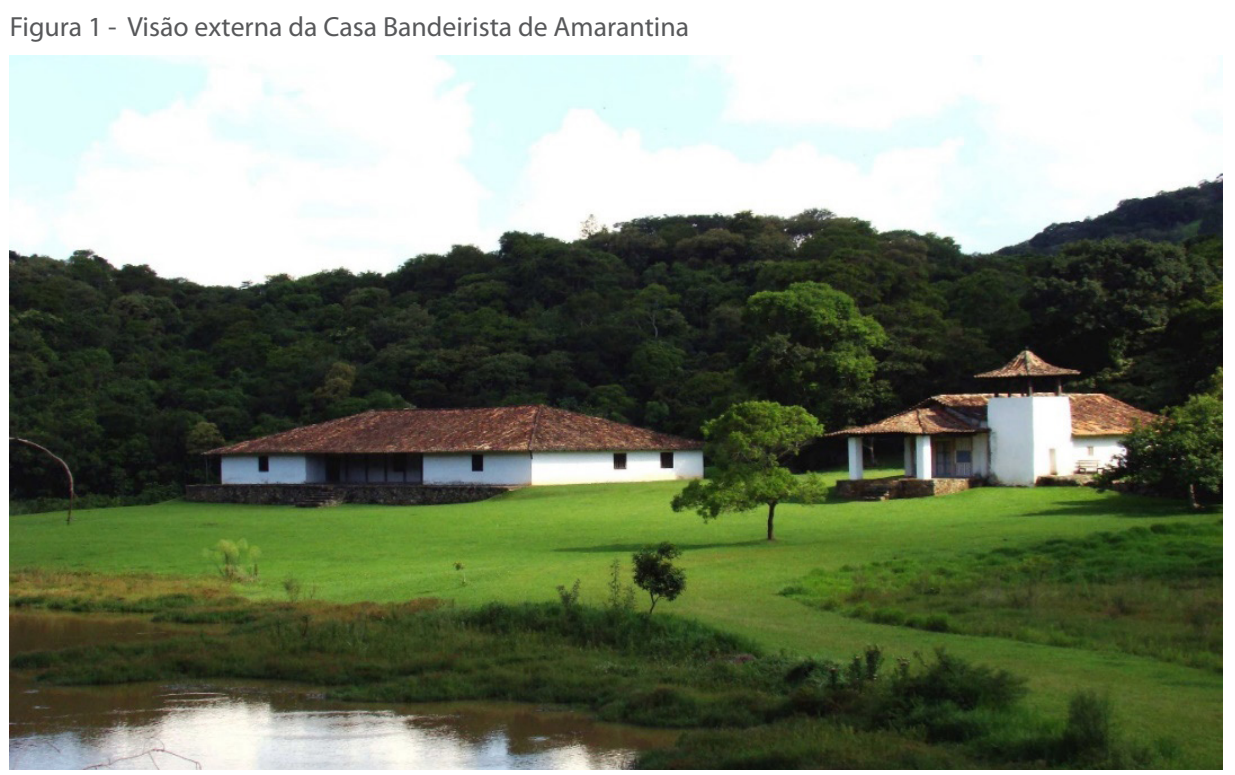

Fonte: Espaço Cultural da Casa Bandeirista de Amarantina - ECCOAR

3 Projeto de pesquisa arqueológica da Casa Setecentista (Casa de Pedra) Amarantina - Ouro Preto/MG. Relatório final, v. 2, julho de 2014. [impresso], p.50.

4 GUIA de Bens Móveis e Imóveis Inscritos nos Livros do Tombo do Instituto do Patrimônio Histórico e Artístico Nacional 1938 - 2009. IPHAN, 2009. p.46. Disponível em: <http://portal.iphan.gov.br/>. Acesso em: 10/10/2014.

5 Descrição longa da Casa Bandeirista de Amarantina. Agradecemos à Maria Aparecida Rita Cássia Vitorino Coelho dos Santos, gestora do ECCOAR da Secretaria Municipal de Cultura de Ouro Preto, pela disponibilização deste impresso. 
Figura 2 - Espaço Cultural da Casa Bandeirista de Amarantina - ECCOAR

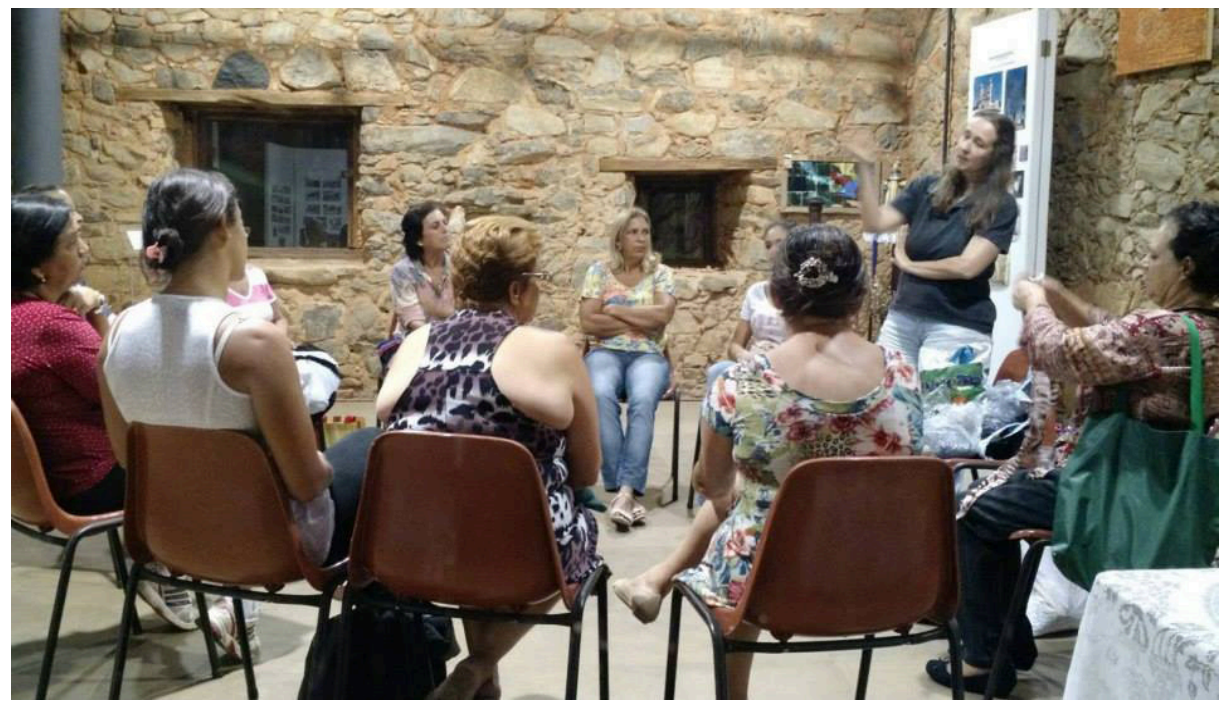

Fonte: Espaço Cultural da Casa Bandeirista de Amarantina - ECCOAR

\section{Métodos}

A pesquisa histórica subsidiou o trabalho de Educação Patrimonial desenvolvido na localidade. Utilizamos como instrumento de interação com a comunidade 'oficinas de rememoração e discussão histórica’ para o desenvolvimento de uma série de atividades. Os pontos norteadores foram os seguintes:

1. Primeira Oficina: trabalhamos os conceitos de sertanista e bandeirante, investindo na desconstrução da imagem clássica de poder dos bandeirantes e na percepção do tipo de patrimônio que envolvia a imagem da Casa de Pedra. Para isso, a oficina começou com uma apresentação oral da problemática e finalizou com uma discussão plenária;

2. Segunda Oficina: Trabalhamos com a gênese do bandeirismo, seus costumes e cultura material, questionando sempre a ideia de patrimônio que estava envolvida. O primeiro passo foi revisitar a problemática da oficina anterior, introduzindo nela a problemática desta oficina, por meio de uma exposição de imagens. Por fim, passamos à discussão, em que novas ideias foram sendo formuladas quanto à imagem clássica versus a imagem crítica dos bandeirismos e sobre o patrimônio;

3. Terceira Oficina: Focamos na mudança do caráter das expedições bandeiristas que, na historiografia crítica, desconstrói a imagem do bandeirante herói, apontando-o ser um homem rude e simples. Focamos, também, no alargamento da cultura patrimonial. Iniciamos a oficina expondo o conceito tradicional de patrimônio e trouxemos questionamentos sobre o termo, ampliando a visão dos participantes para um alargamento do que é patrimônio. Juntamente a isso, demonstramos a rusticidade de vida no sertáo, o que contribuiu para uma crítica tanto ao bandeirante herói, quanto ao conceito tradicional de patrimônio;

4. Quarta Oficina: Nesta oficina, lançamos mais perguntas que respostas, no sentido de aumentar os questionamentos internos de cada participante e de fazê-los pensar sobre o que é patrimônio, qual é o legado bandeirista, como construir uma política patrimonial local. Para isso, começamos a 
oficina com a exposição do filme Bandeirantes, seguido do filme Narradores de Javé, ambos com o objetivo de fundamentar as questóes propostas nas oficinas anteriores e de ajudar a formar, nos participantes, uma visão crítica da história local.

\section{Educaçáo Patrimonial, o jogo de nomes e as apropriaçóes da Casa de Pedra}

Atendendo demanda da direçáo do ECCOAR e de um grupo de moradores do povoado de Amarantina, os alunos de pós-graduação e graduação do curso de História, juntamente com um professor coordenador do projeto, propuseram oficinas temáticas que relacionassem a historiografia do bandeirismo paulista e a história dos sertanistas com as expressóes de patrimônio cultural. ${ }^{6}$ Essa proposta inseria-se no contexto de apropriação e ressignificação dos sentidos que a Casa de Pedra estava sujeita a abrigar.

Focamos nesta relação, porque, no primeiro contato da direçáo do ECCOAR com a Universidade, o propósito era buscar orientaçóes para a criaçáo de um museu do bandeirante, aos moldes da história tradicional. Percebemos que tanto a direção do espaço quanto os moradores estavam muito presos àquela história da Casa de Pedra engessada pelo tombamento promovido pelo IPHAN, em 1963, isto é, tinham como única vertente historiográfica e patrimonial o modelo historicista das décadas de 1930 a 1960 - uma política voltada para as elites, em que o bandeirante-herói é europeizado, onde os bens tombados eram configurados para contar a história dos grandes homens e dos grandes feitos.

A comunidade possuía sobre aquele espaço uma visão ultrapassada do período minerador da regiáo, mas ao mesmo tempo sinalizava não sentir pertencimento àquela história. Contudo, este ensejo contribuiu para que priorizássemos a crítica da história tradicional, aprofundando na ampliação dos usos daquele espaço. Desta forma, propusemos uma relação entre os nomes que indicavam o espaço às histórias que poderiam ser contadas, ou seja, a história do tempo presente, a história crítica, e até mesmo a história tradicional. A execuçáo das quatro oficinas passamos a descrevêlas na sequência, atentando-nos aos propósitos planejados de educação patrimonial e apropriaçôes comunitárias para a Casa de Pedra de Amarantina.

A primeira oficina foi ministrada no dia 14/03/2015. Teve como eixo a conceituaçáo de sertanista ou bandeirante a partir da desconstruçáo da imagem clássica do bandeiranteherói. Participaram deste primeiro dia 40 pessoas, entre elas, membros do ECCOAR, membros da Secretaria de Cultura de Ouro Preto, professores do ensino infantil e fundamental que lecionam na regiáo e moradores locais com idades de 20 a 80 anos. A lista a seguir (Tabela 1) contém a porcentagem relativa da participação de cada pessoa nas oficinas ministradas. Entretanto, em média, houve a participação de 30 pessoas por oficina.

6 A direção do ECCOAR é representada na figura da agente cultural à Maria Aparecida Rita Cássia Vitorino Coelho dos Santos, diretora do espaço.

7 Esta listagem foi cedida pela gestora do ECCOAR, Maria Aparecida Rita de Cassia Vitorino. 
Tabela 1 - Educação Patrimonial - Espaço Cultural Casa Bandeirista de Amarantina - 2014

\begin{tabular}{|c|c|c|}
\hline $\mathbf{N}^{\mathbf{0}}$ & Participantes & PARTICIPAÇÃO \\
\hline 1 & A. R. O.C. & $75 \%$ \\
\hline 2 & A. G. M. S, & $100 \%$ \\
\hline 3 & A. M. J. P. & $25 \%$ \\
\hline 4 & B. A. V. C. S. & $50 \%$ \\
\hline 6 & C. E. S. & $100 \%$ \\
\hline 7 & C. G. R. & $75 \%$ \\
\hline 9 & D. G. C. S. & $25 \%$ \\
\hline 12 & E. M. S. & $75 \%$ \\
\hline 13 & H. A. V. M. O. & $50 \%$ \\
\hline 14 & J. D. B. S. & $100 \%$ \\
\hline 16 & L. F. J. L. & $75 \%$ \\
\hline 17 & L. A. D. A. & $100 \%$ \\
\hline 18 & M. A. G. & $75 \%$ \\
\hline 19 & M. P. X. & $100 \%$ \\
\hline 21 & M. M. O. R. & $25 \%$ \\
\hline 22 & M. A. R. C. V. C. S. & $100 \%$ \\
\hline 23 & M. A. R. & $75 \%$ \\
\hline 24 & M. M. F. & $75 \%$ \\
\hline 25 & M. S. N. & $25 \%$ \\
\hline 26 & M. A. D. & $25 \%$ \\
\hline 27 & N. M. F. & $50 \%$ \\
\hline 28 & N.C. S. & $100 \%$ \\
\hline 29 & R. C. S. & $100 \%$ \\
\hline 32 & R. A. J. & $100 \%$ \\
\hline 33 & S. F. C. & $100 \%$ \\
\hline 34 & S. S. S. & $100 \%$ \\
\hline 35 & S. F. A. S. & $100 \%$ \\
\hline 36 & S. D. G. & $100 \%$ \\
\hline 37 & V. R. D. & $100 \%$ \\
\hline 39 & D. P. S. & $50 \%$ \\
\hline 40 & A. G. S. & $25 \%$ \\
\hline
\end{tabular}

Curso de Extensão da UFOP: Construindo a História Bandeirista da Casa de Pedra de Amarantina

Nesta primeira oficina, foi proposto um confronto de imagens e monumentos de heroicidade (primeira metade do século XX) dos protagonistas de construçáo do território brasileiro. Pretendendo aprofundar as perspectivas críticas, opondo-se às narrativas e ao imaginário nacionalistas, pusemos, ao exame dos participantes, imagens utilizadas pela historiografia recente e relatos que revisassem as noções ou as ideias convencionais sobre os sertanistas paulistas.

Como relacionar essa historiografia crítica de imaginário do bandeirante "clássico", comum à memória histórica dominante em Minas Gerais, à revisão das noçôes de patrimônio e de história local? Primeiramente, apresentamos uma conceituação de patrimônio, numa chave expressiva da cultura popular, para confrontar ou comparar tais sentidos com a memória histórica do bandeirismo que se acostumou a operar. Pôdese também retomar a história do tombamento da Casa, observando-se o contexto de produção dos planos políticos e intelectuais dos anos 1950 e 1960, que se veem enredados ainda ao imaginário dos bandeirantes constituído pela elite da Primeira República, sobretudo de São Paulo. 
O tombamento esteve ligado à gênese do fim século XVII e início do XVIII, ${ }^{8}$ porém reinventado conforme os planos patrimoniais da década de 1960. Segundo Andréa Daer, as práticas patrimoniais andam de mãos dadas com objetivos de poder: "o fenômeno (das práticas de instituiçáo de patrimônio) é resultado de um verdadeiro esforço de agentes do Estado, atuantes no bojo de políticas culturais patrimonializantes e da invenção de objetos patrimonializáveis" (DAER, 2010, p.200).

Buscamos mostrar que os moradores estavam defendendo um patrimônio que, antes de mais nada, diz respeito a todos eles. Náo era nosso objetivo repetir o que já sabiam sobre Bandeirismo, e sim apresentar um novo bandeirante, fazendo-os pensar sobre essa nova imagem, comparada à imagem tradicional. Então, nosso primeiro passo foi abordar a imagem clássica (Figura 3), ou seja, aquele bandeirante imponente, olhar severo, pele clara (europeu), físico robusto de quem adentrava nas matas, roupa impecavelmente alinhada (TAUNAY, 1975). Figura que sempre portava armas, tendo ao seu lado o lugar tenente e, ao fundo, uma paisagem fantástica. Em algumas representaçóes, podemos ainda observar a figura do índio, sempre representado de forma subalterna (ANDRADE, 2008; BLAJ, 2000).

Figura 3 - Pintura de Benedito Calixto, 1903

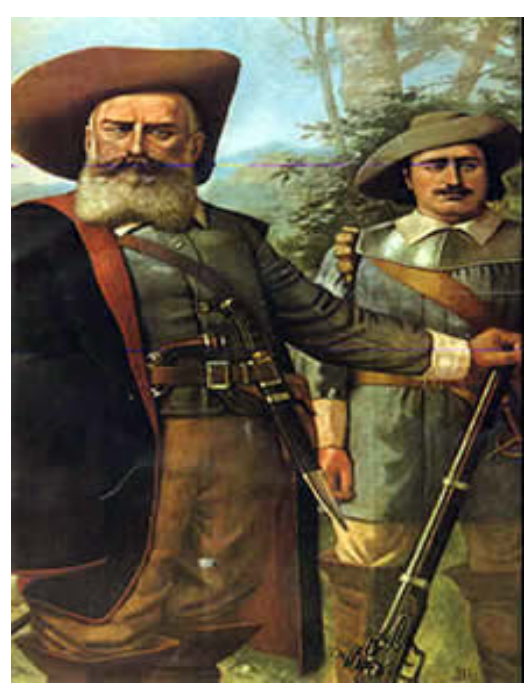

Fonte: Museu Paulista9

A essa imagem contrapomos o bandeirante reconstruído pela crítica histórica (Figura 4), portanto, era um homem que tinha uma aparência cansada, pele morena (maioria dos sertanistas era mistura de índios e portugueses, chamados também de mamelucos), físico magro (natural de quem faz longas caminhadas), roupa velha e adaptada aos perigos da selva. Seus coletes eram feitos de couro de anta, para se protegerem das flechas. A paisagem representada é mais escura e dramática, o arco e flecha aparece como opçáo de arma, já que é leve e ágil e, por fim, o índio como companheiro, responsável pela abertura das trilhas e pela alimentaçáo do sertanista (MONTEIRO, 1994; BLAJ, 2002; ANDRADE, 2008).

8 Segundo o Projeto de pesquisa arqueológico da Casa Setecentista: "A edificação possui sua construção datada do fim do século XVII". PROJETO de pesquisa arqueológica da Casa Setecentista (Casa de Pedra) Amarantina Ouro Preto/MG. Relatório final, v. 2, julho de 2014. [impresso], p. 50.

9 Disponível em:<http://www.mp.usp.br/acervo/selecao>. Acesso em: 10/03/2015. 
Figura 4 - Ilustração de Éber Evangelista

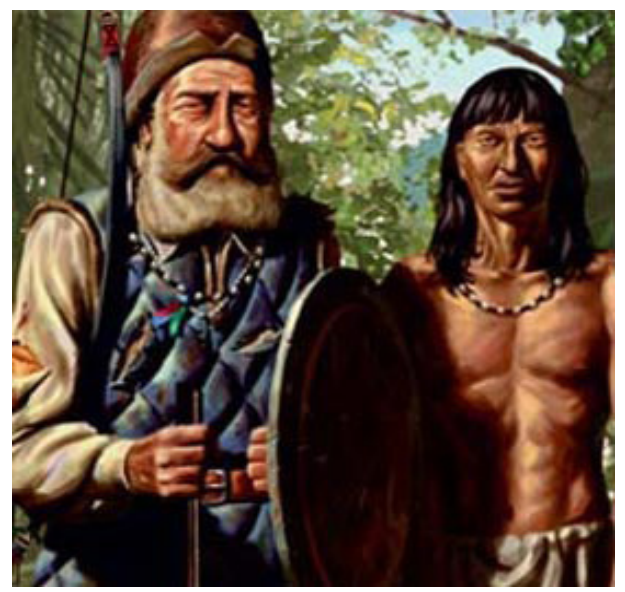

Fonte: revistaescola.abril.com.br10

Seguindo esse caminho, introduzimos a figura do índio, apresentado, agora, como um importante aliado do sertanista e força constituinte do processo de construçáo do Brasil (MONTEIRO, 1994; ANDRADE, 2008).

Quando apresentamos esta nova figura, que acaba sendo mais próxima à realidade dos moradores, e ainda exaltamos a figura indígena, os participantes se sentiram incomodados ao perceberem que o homem idolatrado por muitos anos pela história náo passava de um simples ser humano. Como ressalta John Monteiro (1994), em seu livro Negros da terra: indios e bandeirantes nas origens de São Paulo, além de serem máo de obra para as expediçóes, os índios eram responsáveis pela agricultura, que teve grande importância no século XVIII. Os índios eram os que conheciam o caminho, os que iam na frente, eram eles que, no momento de sede, encontravam água nas folhas das árvores, e num momento de fome conheciam as raízes ou frutas que eram comestíveis ou não. Temos com o indígena uma das bases do processo de formação identitária do Brasil, porém, não é isso que é conhecido.

Esta discussão foi essencial para que os participantes da oficina começassem a entender que a história poderia ser reescrita nos moldes mais próximos de suas vivências e, com isso, o patrimônio se alinharia com a identidade local. Percebemos também certa resistência das pessoas mais velhas diante das desconstruçóes feitas na oficina. Contudo, este foi apenas o trabalho inicial, as outras oficinas viriam a reforçar a desconstrução de uma história tradicional, abrindo espaço para uma nova história a ser contada, algo que fosse mais ligado à cultura local.

A segunda oficina foi ministrada no dia 28/03/2015, na qual explanamos de forma sucinta os costumes e a cultura material tanto dos sertanistas quanto dos índios. Fizemos esta explicação para instigar os participantes a pensar se existem ou existiram referências daquela cultura material indígena e sertanista na comunidade. Esse tema foi caro para a compreensão da construção patrimonial. Abordamos o tema da construção cultural como fruto das características regionais, e constituidora das histórias dos grupos. Segundo François Hartog (2006), o patrimônio é ligado ao território e à memória, e ambos operam como vetores da identidade. E o que seria o patrimônio cultural? Patrimônio cultural é aquele "bem" que precisa ser conservado, de forma jurídica ou não, e que vai além dos

10 Disponível em: <http://revistaescola.abril.com.br/historia/pratica-pedagogica/mudou-imagem-422991. shtml>. Acesso em: 10/03/2015. 
bens que se herdam do passado, mas também aqueles que são produzidos no presente como expressão de cada geração. $O$ patrimônio cultural não é estático, ele se faz todos os dias, ele é vivo.

Art. 216: Constituem patrimônio cultural brasileiro os bens de natureza material e imaterial, tomados individualmente ou em conjunto, portadores de referência à identidade, à ação, à memória dos diferentes grupos formadores da sociedade brasileira [...]. (BRASIL, 1998)

Desta forma, trouxemos à discussão exemplos da cultura material do sertanista do período aurífero, tais como "roça, ferramentas de roçar, criaçóes de pequeno porte como leitóes e aves, prataria envelhecida e 'queimada do fogo', uma caixa de vinhático, roca, poucas roupas" e da cultura material indígena, como o arco e a flecha, utensílios domésticos e de cultivo da terra (ANDRADE, 2013, p. 38). O objetivo desta exposição sobre a cultura material era fazer com que os participantes percebessem a simplicidade do bandeirante que tanto prezavam, como também a importância da cultura indígena para o sertanista.

A partir desta introdução, elucidamos algumas formas de patrimônio cultural, tais como a utilização de plantas como alimento e remédio, formas de trabalhar, plantar, cultivar e colher, pescar, construir moradias, meios de transporte, culinária, expressóes artísticas e religiosas, etc. Para exemplificarmos o objetivo da oficina, um dos palestrantes tocou uma música no instrumento cavaquinho e passou a explanar que tocar seu instrumento, estudar as músicas de sua preferência (como o samba) fazem parte da constituiçáo de sua pessoa, ou seja, ele é resultado daquilo que faz, produz e reproduz. A questão que queríamos discutir com os participantes da oficina era sobre a relação que tinham e mantinham com a Casa e, consequentemente, com o patrimônio que ela representava. Para isso, lançamos as seguintes perguntas: a Casa de Pedra, sendo um patrimônio tombado pelo IPHAN, transmite alguns valores, como modos de fazer, de ser, afinidades do ontem com o hoje? Qual a história que ela nos conta? Os topônimos se complementavam, eram representantes daquele espaço? A história, a cultura material e imaterial tombada pelo IPHAN condiz com a realidade atual da comunidade?

A partir dessas questóes, os moradores se depararam com mais perguntas do que com respostas, e uma delas foi sobre como representar o patrimônio da Casa de Pedra. Qual história se encaixaria melhor para a utilização, otimização e representação do povoado naquele espaço: a história tradicional, a história crítica, a história do tempo presente, ou todas elas? Eles já possuíam algumas ferramentas que foram introduzidas na primeira oficina e reforçadas na segunda, que ajudariam a pensar estas diferentes possibilidades.

Dentro dessa reflexão, fizemos uma abordagem sobre a cultura material que é parte de um fenômeno histórico e é geradora de novas realidades físicas. Explanamos a respeito dos materiais usados tanto pelos bandeirantes quanto pelos índios em seus trabalhos, e da troca de bens que enriqueceu cada vez mais o patrimônio cultural. Além disto, falamos que a cultura material do presente daquele distrito também se refere ao que são, fazem e pensam.

Findamos a oficina com uma discussão que gerou interrogaçóes sobre a própria história local. Alguns chegaram a sinalizar na descrença da história dos heróis em prol da história dos sujeitos; outros sustentaram que a Casa poderia abrigar as várias histórias e alguns poucos conservaram a ideia tradicional. É interessante notar que aqueles que continuaram a apoiar a visão tradicional foram as pessoas mais velhas e algumas 
professoras da educaçáo infantil. Cremos que, no caso dos mais velhos, esta sujeição à história tradicional se deva ao fato de terem sido criados com esta história e o choque da nova visão os faz refletir um pouco sobre seu passado - o que pode gerar um sentimento de ruptura com aquilo que acreditavam pertencer.

Já em relação às professoras, cremos que a história tradicional traz um ar romântico e simples de ser contada, tornando, assim, mais fácil a apreensão dos alunos, e que a história crítica, por necessitar de uma ampliação e autonomia maior da criança, dificulta o trabalho do professor. Devemos lembrar que estes professores, muitas vezes, ministram aulas em salas com 30 crianças, cada uma com seus problemas de aprendizado. Além destas questôes, a identificação com algumas práticas culturais, tais como ter a natureza e o tempo como guia de colheita e plantio, formas de fazer certas comidas típicas confortaram a visão de muitos dos participantes, que se sentiram abraçados por aquele passado.

A terceira oficina foi ministrada no dia 11/04/2015, tendo como tema norteador a mudança no caráter das expediçóes bandeiristas, ou seja, do cativeiro de índios ao descobrimento de metais e pedras preciosas, e, também, a mudança da cultura patrimonializada. Participaram da oficina cerca de 20 pessoas, como professores do ensino infantil e fundamental, a direção do ECCOAR e moradores da comunidade.

Começamos abordando a transiçáo do caráter das expediçóes bandeiristas, que passou do cativeiro de índios para a extração mineral, porém, os sertanistas não deixaram de trabalhar na captura de escravos. Um dos motivos que moveu essa mudança foi o alto valor investido nas expediçóes, pois as viagens exigiam distâncias cada vez mais longas para apresar índios. Além disso, os sertanistas se depararam com a proteção dos jesuítas aos indígenas, defendendo que fossem eles homens livres.

Finalmente, as distâncias dilatadas implicavam o aumento da mortalidade, tanto de sertanistas quanto de cativos. Em poucas palavras, o apresamento de grandes números de cativos tornava-se cada vez mais, mesmo para os colonos mais abastados, uma proposta pouco racional em termos econômicos. (MONTEIRO, 1994, p. 91).

Essa mudança no estilo de expediçáo fez com que fossem mudados também o estilo de vida dos sertanistas, homens que se voltaram naquele momento, por causa das dificuldades enfrentadas na empresa de captura de índios, à procura de pedras preciosas. Com novos hábitos e ofícios, uma nova cultura material surgiria a partir de então e seguiria durante muito tempo na história.

Os sertanistas, com as descobertas auríferas, trouxeram com eles populaçôes que se fixaram nas localidades, formando os arraiais, as vilas e as cidades. Esses locais contaram, além da exploração do ouro, com a agricultura, a pecuária, enfim, com a produção de gêneros que abasteciam os polos mineradores. Dessa nova cultura material que se formou no território de Amarantina, com a passagem dos sertanistas, lançamos aos participantes da oficina uma questáo a respeito da afinidade, da identificação que tinham com esse estilo de vida do bandeirante minerador, e sobre qual era a cultura material daqueles homens.

Ao discorrer sobre a cultura material, o tema das práticas patrimoniais é fundamental para a compreensão do delineamento das histórias que se formaram a partir disso. As práticas patrimoniais, que no Brasil tiveram amparo jurídico no Estado Novo, foram responsáveis pela preservação dos bens materiais e imateriais que ativariam a memória de um passado. ${ }^{11}$

11 A instituição criada no Estado Novo para a formulação, proteção e conservação dos bens patrimoniais foi 
Entretanto, com tudo o que foi discutido nas oficinas, passamos a questionar se a intervenção do Estado basta para sentirmos que algo nos pertence. Somos formados por aquilo que é ditado pelo Estado, ou precisamos da construção histórico-popular; o Estado atuando náo delineia estas representaçóes? Resumindo, para sentirmos pertencimento e que algo nos concerne, precisamos da intervenção do Estado, ou a demanda popular já é o suficiente? $\mathrm{O}$ objetivo destas questôes era fazer com que os participantes da oficina pensassem sobre a dinâmica constitutiva dos patrimônios, tendo, entáo, um posicionamento político frente a este processo.

O caráter seletivo da memória implica o reconhecimento de sua vulnerabilidade à ação política de eleger, reeleger, subtrair, adicionar, excluir e incluir fragmentos no campo do memorável. A ação política, por seu turno, invoca, com frequência, o curso da memória, seja para afirmar o novo cuja eclosão dela depende, seja para ancorar no passado, em marcos fundadores especialmente selecionados, a experiência que se desenrola no presente. (CHAGAS, 2003, p. 136).

Nesse sentido, é primordial a percepção de que a identidade é dinâmica, o que nos faz estar sempre em movimento - algo que está sempre se equacionando.

Com todo esse aparato historiográfico e discussóes promovidas durante as oficinas, abrimos espaços para que os moradores começassem a questionar sobre que tipo de ideal queriam recuperar (quais símbolos) para representar a Casa de Pedra. Nesse caminho, ampliamos o legado patrimonial e relacionamos, para isto, o âmbito imaterial do patrimônio e sua relação com o material. A casa não é somente "pedra e cal", ela carrega consigo múltiplas significaçóes, que são instituídas por cada geração que se apropria dela. É importante pensar que não existe um patrimônio cristalizado, estático, ele sempre se transforma à medida das identidades que o detém.

Durante muito tempo, o patrimônio foi delineado por uma elite intelectual branca que visava a composição de um povo homogêneo e, por isso, os símbolos eleitos por ela eram quase sempre relacionados ao antigo clero e à nobreza, materializados nas coisas corpóreas, ficando de fora os rituais, as artes ameríndias e afro, e as múltiplas identidades que compóem o Brasil (VIEIRA, 2016). A ampliação do conceito de patrimônio ganhou força, principalmente nos países de terceiro mundo - formados pelo sincretismo e pela mistura de povos - depois da Segunda Guerra Mundial. As discussóes se abriram para agregar as várias identidades que compunham certas regióes e seu patrimônio imaterial.

O ocidente só começou a considerar tais questôes depois da aprovação da Convenção do Patrimônio Mundial, Cultural e Natural da Unesco, em 1972, em que foi feita uma reivindicaçáo pelos países do Terceiro Mundo. A partir desse momento, o patrimônio imaterial, natural e a diversidade começaram a fazer parte dos projetos de defesa cultural (SANT'ANNA, 2003, p.53). No Brasil, o patrimônio imaterial foi institucionalizado no ano de 2000 com o Decreto Federal 3.551, de 4 de agosto.

[...] institui o Registro de Bens Culturais de Natureza Imaterial, define um programa voltado especialmente para estes bens. $\mathrm{O}$ decreto rege o processo de reconhecimento de bens culturais como patrimônio imaterial, institui o registro e, com ele, o compromisso do Estado em inventariar, documentar, produzir conhecimento e apoiar a dinâmica dessas práticas socioculturais. Vem favorecer um amplo processo de conhecimento, comunicaçáo, expressão de aspiraçôes e reivindicaçóes entre diversos grupos sociais. O registro é, antes de

o SPHAN - Serviço do Patrimônio Histórico e Artístico Nacional. Foi criado em 1937 e tinha no tombamento o aparato jurídico de proteção a um bem. 
tudo, uma forma de reconhecimento e busca a valorização desses bens, sendo visto mesmo como um instrumento legal. Registram-se saberes e celebraçóes, rituais e formas de expressão e os espaços onde essas práticas se desenvolvem. (IPHAN, 2006b)

Esse foi o pontapé inicial para o surgimento de vários museus de comunidades e do tombamento de manifestaçôes artísticas, que não fossem somente as do catolicismo. A diversidade entrou na pauta patrimonial, e os vários grupos anteriormente subjugados da história requereram seu reconhecimento frente aos poderes públicos. ${ }^{12}$ Além disto, não só o passado entra na pauta patrimonial da atualidade, mas o presente vivido também. Os museus estáo sendo cada vez mais espaços de experiências, tanto do passado, quanto do presente, e náo somente um depositário de peças (GUMBRECHT, 2010; HUYSSEN, 2014).

Nesse topos, a política começa a se abrir para diversidade, o conhecimento não está mais ligado ao patriotismo, mas a uma reflexão crítica da sociedade, que se volta para as várias identidades, o que facilitou muitas das manifestaçôes praticarem suas atividades.

Esse pensamento de que o museu náo necessariamente seja um depositário de peças do passado - muitas vezes sem conexão, nem entre elas nem com o presente ${ }^{13}$ - torna-se essencial para o grupo de Amarantina. Buscamos mostrar que o espaço da Casa de Pedra poderia ser usado de forma mais dinâmica, sem a exclusão da história tombada, porém, com a inclusão de uma história do passado e do presente elaborada por eles mesmos, sendo assim, um lugar de identificaçáo e também de alteridade. Para a otimização e utilização da edificação como um museu dinâmico e atual é necessário avaliar o momento e realizar uma política patrimonial democrática, ou melhor, com a participação da população. Além disso, os múltiplos nomes que possui a Casa já fazem referência às múltiplas apropriaçóes que ela pode abrigar.

O foco da última oficina, que aconteceu no dia 24/04/2015, foi sobre o patrimônio local, isto é, sobre o leque de possiblidades de usos do espaço da Casa de Pedra.

Repassamos a leitura tradicional e crítica a respeito do bandeirismo, do papel indígena e do conceito de patrimônio e seus usos por meio de trechos de dois filmes: o primeiro filme, Bandeirantes (1941), de Humberto Mauro, e o segundo, Narradores de Javé (2003), dirigido por Eliane Caffé. A intenção, ao utilizar esses filmes, foi fazer emergir nos moradores uma visão crítica e ampla a respeito da história.

O filme Bandeirantes foi produzido em 1941, durante o Estado Novo, regime que objetivava a homogeneização da nação, sendo um dos meios para tal a educação cívica. A produção foi feita pelo Instituto Nacional de Cinema Educativo, o qual tinha como finalidade controlar e padronizar a produção cultural com fins de educar o povo, portanto, tal filme fora produzido para passar nas escolas e introduzir os alunos em um molde de cidadáo requerido pelo Estado Novo (MORETTIN, 2013). A figura do bandeirante no filme era do herói. $\mathrm{O}$ roteiro sugerido baseava-se nos escritos de Afonso d'Escragnolle Taunay, que reforçava a genialidade daqueles homens. Segundo este autor, numa concepçáo quase idílica dos bandeirantes: "Depois que se conhecem os pormenores das jornadas intermináveis dos antigos paulistas, fica-se como estupefato e levado a crer que estes homens pertenciam a uma raça de gigantes" (TAUNAY, 1975, p.14).

12 Dentre estes grupos subjugados da história, há os negros, índios, mulheres e pobres.

13 Este ideal estava fortemente entronizado no conceito que os participantes tinham sobre o museu. Possuíam uma visão estática do patrimônio e concebiam o museu como um espaço de exposição de objetos do passado. 
Com esse filme, pudemos contrastar a imagem do herói bandeirante com a figura do novo bandeirante, conjecturado nas oficinas anteriores, e ligá-los à história que os participantes da oficina estavam querendo contar, ou seja, qual bandeirante os define. Ou, mesmo, será que o bandeirante os define? Nesse sentido, para pensar sobre o que são, sobre suas definiçóes, exibimos um trecho de outro filme, Narradores de Javé (2003), dirigido por Eliane Caffé.

O longa trata de um povoado fictício (Javé), que está prestes a ser inundado para a construção de uma hidrelétrica. Para mudar esse rumo, os moradores de Javé decidem escrever a história do local na tentativa de fazê-lo patrimônio e, assim, impedir sua destruição. O filme introduz uma questáo fundamental sobre o patrimônio, que, segundo Dominique Poulout (2009), designava o conjunto de bens transmitidos de pai para filho, conjecturados náo segundo o valor de uso, mas como uma herança que o filho tem o direito de receber. Nesse caso, os bens transmitidos estavam representados na terra que detinham, com os laços que possuíam com aquele lugar e o sentimento de pertencimento.

Para os moradores de Javé, ali estava a história de cada um, e todos sentiram a necessidade de contá-la. Por isto, no título do filme, a palavra narradores está no plural, demonstrando as dimensóes e os infinitos níveis de narrativas. Mostra também as identidades que fazem parte do lugar, a pluralidade da vida, o que reforça as extensóes do patrimônio.

O filme foi uma ferramenta para que pudéssemos associar o desejo de Javé ao desejo dos moradores de Amarantina, isto é, contar a história do local pautada pela história da Casa de Pedra. Nesse sentido, almejávamos que os participantes da oficina aproximassem as várias memórias na elaboraçáo de narrativas, tanto do passado, quanto do presente para a construção patrimonial desejada. Assim, podiam abandonar a concepção engessada que tinham do patrimônio. Interessante notar que esta concepçáo fechada é que fazia com que aquelas pessoas estivessem ligadas à história tombada. E a tônica do filme - a vontade de contarem suas histórias - aproximou-se de seus sentimentos, de suas necessidades, pois, eles também desejavam contar suas histórias. Por isso, entendemos que os moradores de Amarantina devam ter consciência de que todo patrimônio possui precipuamente um 'poder simbólico', o qual extrapola a sua mera concretude.

O objeto tornado patrimônio, monumento histórico, bem cultural ou bem de cultura, não importa o nome que e dê, está sempre funcionando como elemento de estratégias de poder e de resistência que, conforme o momento histórico, visam construir nacionalidades ou identidades; conferir status a determinada produção artística, arquitetônica ou, genericamente, cultural [...]. (SANT'ANNA, 1995, p.8-9).

O patrimônio confere credibilidade para a história contada e incentiva o seu uso, tornando, assim, o bem transformado em patrimônio mais visível e legítimo.

Além disso, apresentamos aos participantes que o jogo de nomes da Casa de Pedra também poderia nos dizer muito da história daquele espaço, ou seja, dos processos e confrontos de poderes constituidores do espaço e de seu tombamento. Portanto, nesse caso, houve a transferência do adjetivo da Casa, isto é, entre um "Historiotopônimo" (bandeirista), ou um "Sociotopônimo" (sertanista), para um "Litotopônimo" (Pedra). ${ }^{14}$

$\mathrm{Na}$ gênese econômica e cultural do sertanismo, a edificação seria uma morada/ unidade de produção e trabalho sertanejo/pastoril/agrário, tendo pouco vínculo com o 
trabalho minerário, assim como era a casa do Planalto paulista, investigada na revista do IPHAN por Mário de Andrade. Por ser considerada uma unidade pastoril, muito mais que unidade minerária, a Casa de Pedra é tombada com o adjetivo de Casa Setecentista, pois abrigava a história de um movimento e características sociais/econômicas contidas nas casas do interior paulista.

No entanto, este nome ainda faz referência a uma história formulada pelas elites, principalmente paulista. Ou seja, no início do século XX, historiadores como Taunay, Salomão de Vasconcellos, entre outros, fizeram do bandeirante o espelho da elite, por isto, a visão do bandeirante-herói. Já em meados do século XX, Sylvio de Vasconcellos amplia o conceito do bandeirismo, unindo-o ao sertanismo, mas mesmo assim em uma visáo elitista.

Portanto, quando a Casa é "descoberta" pelo IPHAN, sua história é contada conforme a gênese do século XVII/VXIII, mas seguindo a lógica patrimonial da década de 1960. Mais tarde, quando ela foi apropriada pela Prefeitura Municipal passou a ser um espaço cultural nomeado como Casa de Pedra. Neste sentido, elucidamos, em um debate com os participantes, que o nome dado por eles à edificação, por si só, evita a reduçáo dos usos locais ao que havia sido patrimonializado. A nova toponímia nos leva a uma eterna contemporaneidade, eterna atualização e isto é significativo para a apropriaçáo patrimonial daquele espaço.

Nessa última oficina, tratamos da significação, do reconhecimento que envolve o patrimônio e sua amplitude, não necessitando mais que seja aquele patrimônio fechado da década de 1960, já que ele pode abrigar em si as várias narrativas, algo que se aproxime de suas experiências e expectativas; e que se identifique com a população local, com suas identidades.

\section{Identidade e patrimônio: por uma "nova" história da Casa de Pedra de Amarantina}

Amarantina, apesar de pertencer a Ouro Preto, não possui muita visibilidade, uma vez que a sede é o centro cultural da região, o que sombreia outras localidades de seu entorno, igualmente significativas.

Durante a primeira República, Ouro Preto foi escolhido como o "cenário histórico ideal" (BECHLER; PEREIRA, 2014, p.67). Esta escolha, feita por intelectuais locais, aconteceu em um período de intensa industrializaçáo e urbanização das cidades, impressa por uma nova ordem, que rompia com um passado colonial e arcaico para repousar nos ideais do progresso. Com isto, Ouro Preto começou a ser vista como uma cidade atrasada e pouco capaz de abrigar a sede administrativa de um Estado. Foi a partir daí que políticos e historiadores do local começaram a escrever a história das Minas Gerais e elegeram a cidade como a origem do Estado, na intenção de mantê-la viva na memória e fazer dela a relíquia dos tempos coloniais (ANDRADE, 2014).

A história de Minas Gerais foi elaborada em cima de um passado assentado na descoberta do ouro e transformado em um tempo glorioso, o que serviu "para tornar equivalentes essa história regional e a história brasileira no que se refere ao passado colonial ou, no mais tardar, para tornar indissociáveis a história colonial e a história das Minas do Ouro". (BECHLER; PEREIRA, 2014, p.68). Essa história acabou por justificar 
a existência da cidade e sua patrimonialização, ficando ela, a partir de entáo, como uma cidade sagrada e intocada, sede cultural do Estado de Minas.

A par de sua diversidade interna, o que sobressai ainda na atualidade do discurso sobre Minas e sobre a mineiridade é um encadeamento histórico que elege como marco fundador e de origem a descoberta do ouro, legitimando memórias que, de diferentes formas e por diferentes meios, são perpetuadas sobre a história mineira ou sobre os mineiros. (BECHLER; PEREIRA, 2014, p.73)

Ao promover o cenário barroco como a essência das Minas Gerais, silenciam-se as outras vozes, ou seja, as outras memórias e histórias que também constituem a região. Um bom exemplo disso é o caso de Amarantina, distrito que, na tentativa de sair da sombra de Ouro Preto e fundamentar sua própria identidade, acabou elegendo um bem que cai na mesma linha de construçáo simbólica feita na cidade, ou seja, selecionou o período colonial e sua pompa criada pelos intelectuais da Primeira República e do Estado Novo.

Esse olhar para um passado cristalizado acabou por desnortear a constituição patrimonial do distrito, que buscou uma origem pautada somente naquele passado tombado e não procurou tirar dos escombros as várias outras memórias que o local possui.

Os moradores de Amarantina se apegaram àquela história - criada para a moralizaçáo do cidadáo - do bandeirante herói e a nomearam o ponto de partida da história local, no entanto não perceberam que essa história tombada era muito distante da história vivida por eles. Além disso, eles estavam presos na concepção de um patrimônio material duro, estático, que não abriga em si diversas camadas de narrativas. Estavam próximos à concepção de patrimônio utilizada pelo SPHAN em seus primórdios, em que um bem era tombado por ser um documento de um passado exemplo, como também pela sua imponência arquitetural e não por contar, em suas várias faces, as histórias de um presente. Os moradores de Amarantina náo percebiam a dinâmica que o patrimônio tem, podendo ser sempre reescrito aos moldes dos atores do presente, e que a Casa poderia abrigar juntamente com a imponência material, algo imaterial.

Quando se fala em patrimônio imaterial ou intangível, não se está referindo propriamente a meras abstrações, em contraposição a bens materiais, mesmo porque, para que haja qualquer tipo de comunicação, é imprescindível um suporte físico. Todo signo (e não apenas os bens culturais) tem dimensão material (o canal físico de comunicação) e simbólica (o sentido, ou melhor, os sentidos), como duas faces de uma moeda. (FONSECA, 2003, p.68).

Eles ainda estavam presos ao patrimônio corpóreo, porém, as práticas culturais fazem parte desse patrimônio e dizem sobre ele. Assim, no espaço da Casa, podem coexistir culturas distintas, como a do bandeirante e a de uma artesá, a de um agricultor e da cavalhada, sem que uma extinga a outra. Portanto, o Projeto de Extensão "Construindo a História Sertanista da Casa de Pedra de Amarantina”, no seu propósito de interação universidade-comunidade, lançou um desafio em busca da necessária reflexão que as pessoas da localidade devam ter em relação à história passada, mas, igualmente, daquilo que os projeta em termos de futuro, da história do devir. 


\section{Consideraçóes Finais}

O projeto buscou criar possibilidades para que os participantes elaborassem juntos os próprios pressupostos historiográficos e patrimoniais, abrindo-se, assim, às várias representaçôes que a Casa de Pedra pode comportar. ${ }^{15} \mathrm{~A}$ história introduzida pelas oficinas baseou-se na crítica das concepçóes de um modelo tradicional ainda seguido pelos moradores locais e lançou, assim, mais questóes a serem trabalhadas, mas que irão, na verdade, clarear o objetivo que almejam alcançar.

Descontruir um bandeirante herói e colocá-lo frente ao bandeirante rude; desmistificar a figura do índio bárbaro e identificá-lo como uma das matrizes nacionais; e derrubar a concepçáo dura do patrimônio de pedra e cal demonstrando suas vicissitudes foram os objetivos do projeto de extensão para que a população pensasse quem são eles e qual é o seu patrimônio.

Pensar o patrimônio não é pensar somente naquela edificação, que sozinha é vazia, mas é pensar seus múltiplos aspectos que fazem parte da constituição de nossa cultura, nossas experiências e expectativas. Assim, a Casa de Pedra de Amarantina pode ser um símbolo mais próximo da cultura local e abrigar as várias camadas identitárias eleitas pela populaçáo, podendo abrigar conjuntamente ou não, um museu, um centro de referência, brinquedoteca, exemplos do artesanato e da culinária local, sem engessar o espaço à uma única história.

\section{Referências iconográficas}

Museu Histórico Nacional. In: Galeria Virtual - Armas que não fazem guerra. Disponível em: $<$ http://www.museuhistoriconacional.com.br>. Último acesso em maio de 2015.

Revista Escola. Disponível em: <http://revistaescola.abril.com.br/historia/praticapedagogica/mudou-imagem-422991.shtml>. Último acesso em maio de 2015.

Espaço Cultural da Casa Bandeirista de Amarantina - ECCOAR. Disponível em: < https:// www.facebook.com/eccoar>. Último acesso em março de 2015.

\section{Referências bibliográficas:}

ANDRADE, Francisco Eduardo de. A invenção das Minas Gerais: empresas, descobrimentos e entradas nos sertões do ouro da América portuguesas. 1. ed. Belo Horizonte: Autêntica Editora/ Editora PUC Minas, 2008.

- Sertanistas das Minas do Ouro: Senhores de tapanhunus e carijós. Politeia: História e Sociedade. Vitória da Conquista, v.13, n.1, p.21-42, 2013.

15 Aproveitando o resultado das oficinas, o ECCOAR nos convidou para a elaboração de mais oficinas, voltadas agora para a Cavalhada, cultura típica do local. Estas oficinas foram ofertadas no ano de 2015, com o nome: Correndo na história: festa, cavalhada e patrimônio de Amarantina. 
A "barca agitada no mar de Tiberíades" e as fronteiras de Minas Gerais na História de Diogo de Vasconcelos. IN: ROMEIRO, Adriana, SILVEIRA Marco Antônio (orgs). Diogo de Vasconcelos: o ofício do historiador. Belo Horizonte: autêntica, 2014.

ANDRADE, Rodrigo Melo Franco de. Rodrigo e o SPHAN; Coletânea de textos sobre o patrimônio cultural. Rio de Janeiro: Ministério da Cultura, Fundação Nacional Pró-Memória, 1987.

BECHLER, Rosiane Ribeiro; PEREIRA, Júnia Sales. Ouro Preto de todos os tempos: sentidos e efeitos do patrimônio na condição histórica da cidade. Revista História Hoje, v.3, n.6, p.6790, 2014.

BLAJ, Ilana. Mentalidade e Sociedade: Revisitando a historiografia sobre São Paulo Colonial. Revista de História, n.142-143, p.239-259, 2000.

- A trama das tensões: o processo de mercantilização de São Paulo colonial (1681-1721). São Paulo: Humanitas/FFLCH/USP: Fapesp, 2002.

BRASIL. Constituição Federal de 1988. Disponível em:

<http://portal.iphan.gov.br/uploads/legislacao/Constituicao_Federal_art_216.pdf.> Acesso em: 20/03/2015.

CHAGAS, Mário. Memória Política e Política de Memória. In: ABREU, Regina; CHAGAS, Mário. (Orgs.). Memória e Patrimônio: Ensaios contemporâneos. Rio de Janeiro: Lamparina, 2003.

DAER, Andréa. Práticas patrimonializantes e objetos patrimonializados. Est. Hist., Rio de Janeiro, v. 23, n. 45, p. 199-202, jan./jun. 2010.

DECRETO FEDERAL LEI N²5, de 30 de novembro de 1937. Organiza a proteção do patrimônio histórico e artístico nacional. Disponível em:

<http://www.planalto.gov.br/ccivil_03/decreto-lei/del0025.htm>. Acesso em: 22/11/2013.

ESPAÇO Cultural Casa de Padra de Amarantina - Descrição longa da Casa Bandeirista de Amarantina. [impresso]. Amarantina, 2010.

FERNANDES, Patrícia Damasceno; ARANTES, Taís Turaça; COSTAS, Natalina Sierra Assêncio; GOMES, Nataniel dos Santos. Estudos Onomásticos: uma análise de nomes de logradouros Campo-Grandenses. Web-Revista Sociodialeto. Núcleo de Pesquisa e Estudos Sociolinguísticos, Dialetológicos e Discursivos. v. 6, n.6, Jul. 2015.

FONSECA, Maria Cecília Londres. Para além da Pedra e Cal: por uma concepção ampla de patrimônio cultural. In: ABREU, Regina; CHAGAS, Mário. (Orgs.). Memória e Patrimônio: Ensaios contemporâneos. Rio de Janeiro: Lamparina, 2003.

GUIA de Bens Móveis e Imóveis Inscritos nos Livros do Tombo do Instituto do Patrimônio Histórico e Artístico Nacional 1938 - 2009. IPHAN, 2009.

GUMBRECHT, Hans Ulrich. Produção de presença: o que o sentido não consegue transmitir. Rio de Janeiro: Contraponto; Ed. PUC-Rio, 2010. 
HARTOG, François. Tempo e patrimônio. Varia Historia, Belo Horizonte, v. 22, n. 36: p.261-273, Jul./Dez. 2006.

HUYSSEN, Andreas. Culturas do passado-presente: modernismos, artes visuais e políticas da memória. Rio de Janeiro: Contraponto, 2014.

IPHAN. Instituto do Patrimônio Histórico e Artístico Nacional. Disponível em: http://portal.jphan.gov.br/ pagina/detalhes/234. Acesso em: 20/03/2014.

MONTEIRO, John Manuel. Negros da terra: índios e bandeirantes nas origens de São Paulo. São Paulo: Companhia das Letras, 1994.

MORETTIN, Eduardo. Humberto Mauro, cinema, história. São Paulo: Alameda, 2013.

POULOT, Dominique. Uma história do Patrimônio no Ocidente, séculos XVIII-XIX: do monumento aos valores. São Paulo: Estação Liberdade, 2009.

PROJETO de pesquisa arqueológica da Casa Setecentista (Casa de Pedra) Amarantina - Ouro Preto/MG. Relatório final, v. 2, jul. 2014. [impresso].

SANT'ANNA, Márcia. Da cidade-monumento à cidade-documento: A trajetória da norma de preservação de áreas urbanas no Brasil (1937 - 1990). Dissertação (Mestrado) - Programa de Pós-Graduação em Arquitetura e Urbanismo. Universidade Federal da Bahia, Salvador, 1995.

Marcia. A face imaterial do patrimônio cultural: os novos instrumentos de reconhecimento e valorização. In: ABREU, Regina; CHAGAS, Márcio. (Orgs.). Memória e Patrimônio: Ensaios contemporâneos. Rio de Janeiro: Lamparina, 2003.

TAUNAY, Affonso d'Escragnolle. História das Bandeiras Paulistas. 3. ed. São Paulo: Melhoramentos; Brasília: INL, 1975.

VASCONCELOS, Diogo de. História Antiga das Minas Gerais. 1. ed. Rio de Janeiro: Imprensa Nacional, 1948.

VASCONCELOS, Salomão de. Bandeirismo. Biblioteca Mineira de Cultura, v.e XV. Belo Horizonte, 1944.

VIEIRA, Pollianna Gerçossimo. Salomão de Vasconcellos e a consagração da "Atenas Mineira" em Monumento Nacional (1936-1947). Dissertação (Mestrado) - Programa de Pós-Graduação em História. Universidade Federal de Ouro Preto, Mariana, 2016. 